\title{
Skaitmeninès reprodukcijos: katalogo aprašų modeliai ir elementai
}

\author{
Sofija KLARIN
}

Nacionaline ir universiteto biblioteka, Zagrebas, Kroatija, el. p. sklarin@nsk.hr

Straipsnyje pristatomos skaitmeninit reprodukciju ypatybès ir rüšs bei išryškinamos problemos, atsirandancios sudarant bibliografinius aprašus. Siekiant palygint fahsimiliı ir mikrografiniı reprodukciju aprašo modeli, pateikiama Kroatijos katalogavimo taisyklit ir ISBD(ER), ISBD(G), ISBD(M) ir ISBD(NBM) murodym analize, išvardijami aprašo elemenai ir UNIMARC formatq atitinkantys laukai. Straipsnyje taip pat pateikiamas skaitmeninil reprodukciju aprašı modelis, taikomas Kroatijos nacionalines ir umiversitelo bibliotekos Zagrebe vukdomame isteklit skaitmeninimo eksperimentiniame projekte.

Reikšminiai こodžiai: skaitmeninès reprodukcijos; katalogo aprašas; versijos aprašas; standartai; ISBD(ER); ISBD(NBM); UNIMARC.

\section{Ivadas}

Bibliotekos, pradedančios vykdyti iš jų fondu atrinktų išteklių skaitmeninimo projekta, turi ne tik apibrèżti techninius, organizacinius, teisinius, finansinius ir kitokio pobūdžio projekto aspektus, bet ir išspręsti skaitmeninių reprodukcijų katalogo aprašụ sudarymo klausimą. Svarstomieji ištekliai yra elektroninių išteklių rūšis, kurios bendri apibūdinimai atsiranda dẻl skaitmeninès ju fornos, tuo tarpu kiti apibūdinimai priklauso nuo jų kūrimo metu taikomos specifinès procedūros ir yra glaudžiai susiję su tam tikrais konkretaus skaitmeninimo projekto tikslais. Kiekvienas skaitmeninimo projektas yra išskirtinis dẻl skaičiaus ir rūšies reprodukcijų, kurių kūrimas priklauso nuo vartojamos technines ir programinés irangos, skaitmeninamo ištekliaus rūšies ir numatyto vartojimo tikslo. Svarbu itraukti informaciją apie suskaitmenintus išteklius ị bibliotekos kataloga, susieti originalus su ju reprodukcijomis, kad vartotojai galètu susipažinti su visomis egzistuojančiomis dokumento formomis, taip pritaikant jungiamojo katalogo paskirtị ir funkcija.

ISBD(ER), kuris apibrèžia ir skaitmenines reprodukcijas, nesiūlomas aiškus aprašo modelis ir galutinis sprendimas paliekamas bibliografijos centrams. Be to, standarte konkrečiai neapibrèžtas skaitmeninių reprodukcijų skirtingu versiju aprašas. Jame taip pat aiškiai neapibrěžta, kokiu būdu reikia užrašyti specifines aprašo pastabas, pavyzdžiui, pastabas apie skaitmeninių reprodukciju ir jų versijų vartojimo sąlygas ir teises.

Kiti probleminiai klausimai yra susij̨̨ su skaitmeninių reprodukcijų kompiuterinio įrašo formato pasirinkimu. Formatas, tradicinis arba naujesné irašu sudarymo schema pagal metaduomenis, pasirenkamas remiantis projekto rūšimi ir tikslais, skaitmenines reprodukcijas gaminančios istaigos tipu bei finansine parama, kurią projekto metu galima išleisti katalogavimo tikslams.

Siuo metu Kroatijos bibliotekos žengia pirmuosius žingsnius, skaitmenindamos jose sukauptus ištcklius, ir susiduria su skaitmeninių reprodukciju apdorojimo problemomis. Sprendžiant katalogavimo problemas visada naudinga pasikliauti šalies katalogavimo taisyklèmis, net jei problemos susijusios su išteklių rūšimi, kuri neittraukta i taisykles. Evos Veronos sudarytame leidinyje Pravilnik $i$ prirtucnik za izradbu abecednih kataloga (,Abẻcèliniц katalogı sudarymo taisyklès ir vadovas" toliau tekste Vadovas) pateikiamas aiškus konceptualus faksimilių aprašo modelis, kuri taip pat galima pritaikyti skaitmeninems reprodukcijoms, nes aprašai panašūs tuo, jog sicjasi su reprodukuotu dokumentu. Galimybę pasinaudoti Vadovu, sprendžiant problemas aprašant skaitmenines reprodukcijas, reikẻtu ištirti, lyginant ji su kitais aprašo modeliais, kurie remiasi skirtinguose ISBD pateikiamais nurodymais. 


\section{Terminologija ir ištekliı̨ apibréžimai}

Prieš kataloguojant skajtmenines reprodukcijas pirmiausia reikia nustatyti aprašomo bibliografinio viencto rūšs̆, po to pasirinkti aprašui taikytinus standartus ir formatus, atsižvelgiant i specifinius konkretaus projekto ar bibliotekos reikalavimus bei būstmą skaitmeninès reprodukcijos paskirti.

Skaitmeninimas - tai procesas, kurio metu išlekliaus turinys ir išvaizda skenuojama, kopijuojama, fotografuojama arba kitokiomis irašymo priemonèmis ${ }^{1}$ perkeliama i skaitmeninę formą. Originalaus šaltinio skailmeninimas vadinamas "pirminiu“ skaitmeninimu, tuo tarpu kitų netiesioginių šaltiniu skatmeninimas yra „antrinis“, kai skaitmeninama originalo fotografinè teprodukcija arba mikrofilmas.

Skaitmeninimo metu gaunami elektroniniai failai arba, pagal ISBD(ER) terminologijఔ, clektroniniai ištckliai. Šios rüšies elektroniniaj ištekliai kuriami kitaip nei grynieji skaitmeniniat ištekliai. Analogiškai faksimilių apibrěžimui, išttekliai, sukuriami skaitmeninant kitų laikmenu turinius, galètụ būti apibrèžti kaip ,tiksli rašyto arba spausdinto teksto, piešinio, paveikslo ar kito vieneto reprodukcija", pagal kurią (skaitmeninè), faksimilè gali perteikti tikraji, padidintą arba sumažintą originalą"?

Skaitmen inimo produktai dažnaj vadinami suskaitmenintais išlekliais, tačiau mikrofilmavimo produktai vadinami mikrofilmuc reprodukcijomis, mikroformomis, mikrofilmats ir t. t., terminas mikrofilmuoti istekliai nevartojamas. Todè] tam, kad būtu galima atskirti dvi reprodukciju formas, kurios, tiesa sakant, turi labai panašius bibliografinius apibūdinimus, šiame straipsnyje ištekliai, gauti skaitmeninimo metu, vadinami skaitmoninèmis reprodukcijo$m^{3} s^{3}$.

\section{Skaitmeninių reprodukcijų rūšys}

Vieno iš skaitmeninimo procesu, skenavimo, metu stkuriami failai, kuric dažniausiaj yra pricinami, vartojami ir pateikjami internete, sjekiant netiesiogiai išsaugoti originalą. Pavyzdžiui, Mathew Woollard išskiria dvi skaitmeninił reprodukciju rūšis: skaitmenini sturogala, t. y. aukščiausios kokybès skailmeninę reprodukcija, ir skaitmeni-

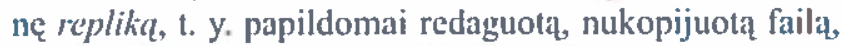
kuris turi papildomos vertès". Toliau pateikiamą klasifikacịją ir pasirinktą skirtingų skaitmeniniu reprodukcijų rūšiı terminologija reikètu vertinti kaip negalutinę, nes tikrasis projckto tikslas ir yra apibréžti skaitmeniniu reprodukciju versiju rūšis ir skaičiı, kaip jau buvo minèta anksčiaus .

\subsection{Skaitmeninis originalas}

Pirmoji originalios medžiagos kopija vadinama skaitmeniniu originalu (faksimilès originalu) ${ }^{\text {t. }}$ Tai aukštos kokybés vaizdinis failas, dažniausiai TIFF formatu, kurio nereikia papildomai apdoroti ar sumažinti? dinius failus galima naudoti kaip pagrindą sukurti skaitmeniniam originalui, kadangi (iki realaus irodymo laipsnio) jie atvaizduoja originalo turinị ir išvaizda ${ }^{x}$.

Skaitmeninị originala galima apibūdinti kaip pagrindine issangojimo kopija (archyvines kokybés išsangojimo surogatq, surogatq issaugojimui), jei ji susideda iš vaizdiniu failu, kuriuose yra viso originalo kopija ir jei ji sukurta pagal rekomendacijas archyvinès kokybès išsaugojimo surogatams gaminti. Europos mikroformu originalu registras (European Register of Microform Masters EROM $M$ ), kuris priima ir skaitmeninil reprodukciju bibliografinjus irašus, reikalauja, kad išsaugojimui skirti

'Kai kuriuose profesiniuose strapsniuose terminai, skatmeninimas" is .skenavimas" vartojami kaip sinonimai, luo tarpu kiti atoriai sinoni-

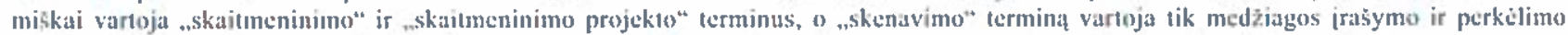

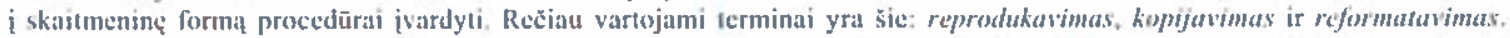

: Verona, Eva. Pravilnik i priručnik za izrabu abecednilı kataloga : prvi dio : odrednice i redalice. Zigreb : 11 rvatsko bibliotekarsko društvo, I986, p. 379.

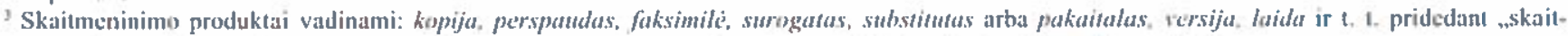

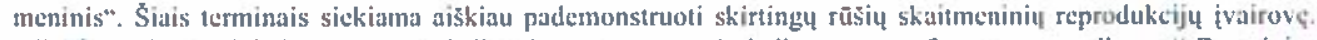

+ Woollard, Mathew. Digital resources : clallenging use or users" challenges : conference procecdings. // Examining the impact of digitization upon sefolarship in the humanities, 7 July 2003 / Institutc of Historical Rescarch. hte://www history.ac. uk/conferences/digitisation2003/woollard. litml (2003-12-12).

${ }^{3}$ Australijos nucionaline biblioteka vykdo skaitmeninime projckta, kurio metu kuriami șį lipy duoment failai: pagrindinis failas, antrasis pagrindinis failas, sumažinta kopija, apžvalginé kopija, moksline kopịj, spausdintinc kopija ir interaktyvi kupija. Cf: Alvaizdai pristatomi: http:/l www.nla.gov, au/digital/delivery/html (2003-10-10).

- Terminu skaimoninis originalas kartais jvardijami išckliai, pradžioje sukurti clektronine fonma tam, kad velia būty galima paskclbti spausdinta versija arba perkelti i kit i clektroninę formq. T’okiais alvejais skaitmeninis originalas neskelbiamas. Kroatijos profesineje literatüroje taip pat vartojamas terminas digifahe masfer dafoleke (cf: Vrana, Radovan. Digitalni Babilon : utvrdivanje kriterija za vrednovanje kvalitele izgradnje i sad̛žaja digitalnih zbirki i usluga. // 6. scminar Arhivi, knjižnice, muzcji : mogucinosti suradnje u okružcnju globalne jnformacijske infrastrukture : zbornik radova / edited by Tinka Katic. Zagreb : Wrvatsko knjižnicarsko društvo, 2003. pp. 49-61.) ir master-slika (ce.: ZJodi, Goran. Muzejska vizualna dokumentacija u digitalnom obliku : magistarski rad. Zagreb : Filozofiki fakultet, 2003. ).

7 Daugiau informacijos apic skcnavimo procedūra: Zlodi, Goran. Ibid., p. 18.

"Scliwartz, Werner. On the importance of recording microforms and digitised versions produced for preservation on the international level. with a focus on standards. htp://liber, library, uu.nl/publish/articles/000055/article content/htm (2003-12-14). 
originalai būtų minimalios 600 taškų colyje raiškos". Skaitmeninio originalo nebus įmanoma peržiūrètj kompiuteriu dèl jo failų dydžio, taip pat siekiant apsaugoti nuo neleistino vartojimo. Iš esmès skaitmeninis originalas vartojamas kaip šaltinis naujoms kopijoms, redaguotoms ir sutrumpintoms originalios reprodukcijos versijoms, kurios tinkamesnès prieigai ir vartojimui gaminti.

\subsection{Kopijos prieigai ir vartojimui}

Naujos reprodukcijos versijos sukuriamos iš skaitmeninio originalo (dar vadinama išvestiniais atvaizdais arba failais), užtikrinant skaitmeninio originalo kaip , archyvinès kokybès surogato", nevartojamo kitiems tikslams, išsaugojimą.

Skaitmeninio originalo versijos vadinamos toliau išvardylais terminais, kurie priklauso nuo paskirties: vartotojo kopijos, informacines kopijos, vartojimo kopijos, skolinamos kopijos arba prieigos kopijos. Panašiai kaip mikrofilmo reprodukcijos, pirmoji skaitmeninio originalo versija gali būti taip pat vadinama tarpine kopija ${ }^{10}$. Tarpine kopija (taip pat vadinama pagrindine kopija) dažniausiai pagaminama suglaudinus pagrindini skaitmenini failą $\mathrm{i} \mathrm{ki}-$ tą formatą, pavyzdžiui, JPEG. Glaudinant failą nebūtina papildomai jo redaguoti arba atvaizdą galima apdoroti, apkarpant ar išlyginant kraštus. Bibliotekose originalas vartojamas kitoms kopijoms ir versijoms kurti.

Vartotojo kopijos sukuriamos vadovaujantis konkretaus projekto poreikiais. Jose gali būti pateikiami dar labiau suglaudinti ar apdoroti vaizdiniai failai arba kitu tipu failai. Dèl jų dydžio apdorotas versijas paprasčiau vartoti nei archyvinès kokybès originalus (pvz., ekrano užsklandai, sukurti pažintiniam CD-ROM ir t. t., vartoti, skolinti arba nusipirkti, publikuoti ir platinti internete)" ${ }^{\prime \prime}$.

I vartojimo kopijas taip pat galima itraukti rekstinins failus arba versijas, kurios sudaromos iš vaizdinjų failų, pritaikius vieną iš optinio ženklų atpažinimo programų. Atrodo, kad tokios kopijos yra praktiškesnés nei vaizdiniai failai đẻl redagavimo ir paieškos galimybiu ${ }^{12}$.

Reprodukcijoms, skirtoms prieigai ir vartojimui, priklauso ir interaktyvis failai arba versijos. Jos sukuriamos, suglaudinus skaitmenini originalą arba tarpinę kopiją pritaikius tinkamą programinę iranga, kuri leidžia interaktyviai matyti vaizdinio failo turini ir pritraukti konkrečią atvaizdo dal $i^{13}$.

Vartojimui ir pricigai skirtos reprodukcijos taip pat netiesiogiai išsaugo originalą, nes sumažeja jo vartojimo intensyvumas ir galimybè jam pakenkti. Matydami ir lygindami net ir labai sumažintus atvaizdus, pavyzdžiui, sttmažintas kopijas, vartotojai gali surasti norimą dokumentą ir užsisakyti jo originalą.

\section{Skaitmeninių reprodukcijų aprašo modelio pasirinkimas}

Knygos, rankraščio, žemélapio ar lajkraščio słaitmenincis reprodukcijos katalogavimo procesas pradedamas pasirenkant reprodukcijos aprašo modeli, po to pasirenkamas modelis, kuris bus vartojamas aprašyti ivairioms jos kopijoms. Aprašo modelio pasirinkimas priklauso nuo tokiu faktorių: ar aptariama skaitmeninè reprodukcija yra nauja kūrinio laida, kuriai reikia sudaryti atskira katalogo vienetă, ar reprodukcija yra tik išsaugojimui arba originalo vartotojo kopija, kurią reikia tik trumpai apibūdinti kaip paslabų dali, pridedamą prie bendrojo originalo aprašo, ar i kurio aprašą reikia itraukti fondo duomenis. Nors gali pasirodytí, kad šj dilema paprastai išsprendžiama pritaikius faksimilių ir mikroformı aprašo modeli, konkrečių skaitmeninimo projektu metu taikomi aprašo modeliai rodo ką kita ${ }^{1+}$. Priežastys slypi katalogavimo taisykliu skirtumuose, taisyklių interpretacijose ${ }^{15}$, konkrečios bibliotekos

\footnotetext{
" http://ww w eromm.org/standards.htm (2003-12-14).

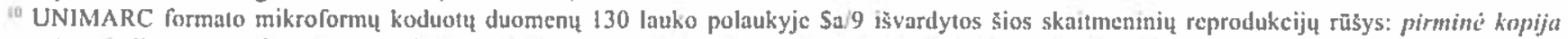

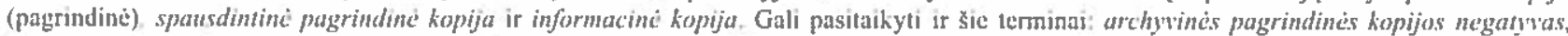

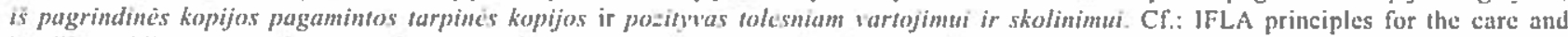
landling of library material / compiled and edited by Edward P. Adcock with the assistance of Marie-Thérese Varlanoff and Virginie Kremp. Paris : IFLA PAC ; Washington DR : CLJR, 1998, p, 67.

"Zlodi, Goran. Ibid.

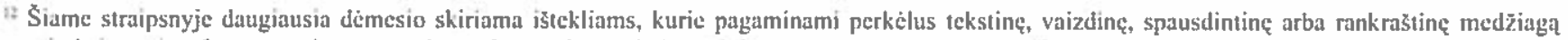
i skaitmeninç formą, nuskenavus arba nufotografavus skaitmeniniu fotoaparatu. Jame neaptariamas garso jasašu, filmy ir kitos medžjagos perkèlimas i skaitmeninç formą, nors bendruosius anksčiau pristatyto modelio, skirto katalogo aprašans sudaryti, būdus galima pritaikyti ir šioms medžiagos rüšims.

"Dažniausiá jie sukuriami didelès apimties medžjagos skaitmeninèms reprodukcijoms arba dokumentams, kuriụ miniatiūrines detales reikia padidinti (pvz, žemélapiai, miesto planai ir t, t.), pavaizduoti.

it Copeland, Ann. Works and digital resources in the catalog : slectronic versions of Book of Urizen, The Kelmscolt Chaucer and Robinson Crusoe. // Calaloging \& classification quarkerly 33, 3-4 (2002), p. 171.

${ }^{15}$ Angly-amerikiecių katalogavimo taisyktių (AACR2) antrosios jajos II-ajame skyriuje nurodoma, kaip sudaromas atskiras katalogo vienetas mikrofilmo reprodukcijoms, taisyklés gali būti analogiškai taikomos shaitmeninems scprodukcijoms aprošyti. Taçiau JAV Kongreso biblioteka nesutinka su tokio tipo aprả̌is ir teigia, kađ jis bătt nepraktiškas tick vartotojams, tick patiems bibliotekininkams, o victoj to siülo đuomenis

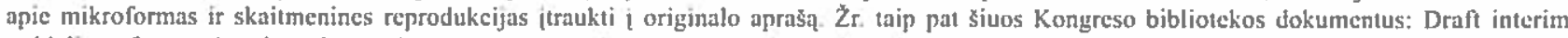
guidelines for cataloguing electronic resources. http://lcweb.loc.gov/catdir/cpso/dcmb19_4.html. (2004-02-04).
} 
praktikoje, kuria siekiama patenkinti vartotoju poreikius ir skirtingu bibliotekц informacijos sistemu, patenkinančiu konkrečias užklausas, vartojime, taip pat individualių skaitmeninimo projektų finansivimo galimybèse.

Tai, kad šią problemą būtina neatidẻliotinai išspręsti, patvirtinta diskusijos apie skaitmeninių reprodukcijц aprašo modeli, vykusios $2003 \mathrm{~m}$. liepos 28-30 dienomis Frankfurte, surengto Pirmojo tarptautinio eksperty pasitarimo dél tarptautiniu katalogavimo taisyklių (International Meeting of Experts on an International Catalograing CodeIME ICC), metul's. Diskutuodami apie vieno kūrinio jvairių formy aprašus, ekspertai sutiko, kad kiekvienaj formai reikia sudaryti atskira iraš̨ tačiau vis dẻlto numatyti galimybę išvardyti duomenis apie reprodukcija kartu su jos originalo įrašu.

Skirtumai aprašant vieno kūrinio ivairias formas rodo, kad nèra bendro tarptautinio standarto, kuri bibliografijos centrai galètu taikyti, kataloguodami originalą ir jo reprodukcijas.

ISBD(G) valstybinés bibliografijos centrams rekomenduojama sudaryti atskirus bibliografinius ịrašus ištekliams, kurie prieinami ivairiomis formomis, laikmenomis ar atvaizdavimo formatais, nors jic gali nuspręsti taikyti ir kitus aprašo modelius, atsižvelgdami $i$ bibliotekos ir jos katalogo vartotoju poreikius ${ }^{17}$. Tam tikra prasme ISBD(ER) taip pat skatina priimti skirtingus sprendimus, kurie akivaizdžjai prieštarauja tam, kad ISBD būtu pripažintas standartu, taikomu keičiantis bibliograliniais irašais tarplautiniu mastu ${ }^{18}$.

Analizuodama senujju išteklių skaitmeniniu reprodukciju aprašą IFLA tyrime Functional Requirements for Bibliographic Records (,Funkciniai reikalavimai bibliografiniams (rašams") pasiūlyto sprendimo kontekste Tinka Kitić atkreipè dèmesł, kad skaitmeninès reprodukcijos (kaip ir mikrografiness reprodukcijos) yra nauja laida, t. y. nauja kūrinio pasirodymo forma, kuriai reikia sudaryti naują bibliografini irašą".

\subsection{Faksimiliu katalogavimas}

Kaip jau minèta, Vadove paletkiamos aiškiai suformuluotos nauju laidu, atspaudu ir faksimilių aprašo taisyklès, pagat kurias reprodukcija arba antroji kūrinio pasirodymo forma nusakoma kaip nauja laida, kuriai reikia sudaryti atskirą katalogo irašą. „Faksimiliné kopija arba antrasis perspaudas, padarytas naudojant spaudos forma fotomechanini, fotolitografinị ar kokị kitą būdą, tinkamą surinkti senają laida turètı̨ būti vadinama nauja laida"s]". Faksimilinei kopjjai reikia sudaryti atskirą bibliografini irašą ir pateikti pastabą (pastabas) apie jos originala.

Kopijos aprašo elementai skiriasi nuo originalo aprašo elementu, pradedant informacija apie publikavima, kartais skiriasi net kopijos ir originalo antraštés (faksimilès apraše antraštè gali būti sutrumpinta arba pakeista, jei faksimilè išletsta pridèjus nauja pirmaji puslapi), atsakomybẻs duomenimis tik apic faksimilinę laidą leidybine informacija, fiziniais duomenimis, pastabomis apie kopijos sukūrimą ir t. t. Daugumą nurodymų, paskelbtu Vadove ir ISBD(M) apic faksimilių apraša, galima laikyti ir sudarant skaitmeninių reprodukcijų aprašus.

\subsection{Mikrografinių reprodukcijų katalogavimas}

Aprašant mikroformas, funkcionuojančias kaip kitu kūriniı̨ reprodukcijos, vadovaujamasi ISBD(NBM) pateiktais nurodymais. Šic nurodymai sudaryti pagal anksčiau aprašytą faksimilių aprašo modeli. Nors mikroformų aprašas it nèra tiesiogiaj ịtrauktas i Vadova ${ }^{21}$, jo autore $\mathrm{E}$. Verona šj klausima pamini $1977 \mathrm{~m}$. parašytame straipsnyje $\mathrm{e}^{22}$, kuriame ji aiškina: „Jei vienetas yra perkeliamas $\mathrm{i}$ kitokią laikmeną nei jo originalas, sudarant vieneto aprašą reikia remtis naujaja laikmena. Kitaip tariant, jei spausdintas leidinys yra irašytas i mikrofilma, pirmiausia jis turi būti aprašytas kaip mikrofilmas, vadovaujantis ISBD(NBM) nurodymais, o originalaus leidinio duomenys pateikiami pastabų forma. Nors ši procedūra atitinka tarptautini susilarimą, jškyla klausimas, ar ji visada yra geriausias sprendimas vartotojuit ${ }^{423}$.

Th IME ICC : report of the Ist Mceting, Frankfurt, Germany, July 28-30, 2003 / reported by Barbara B. Tilletl. Jutp//wwwddb.de/news/pdf/ ime icc report berlin paf (2003-10-02)

"ISBD(G) : General international standard bibliographic description : draft for world wide review / recommended by the ISBD Revicw Group. 2003 revision.

IA ISBD(ER) : Medunarodni standardni bibljografski opis elektroničke grade : preradeno izdanje ISBD(Cla)-a : Medunarodnoga standardnoga

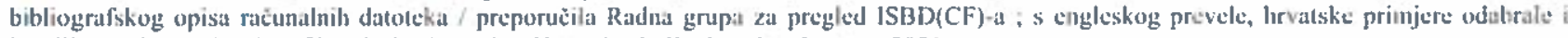
izradile Tanja Ẻszina i Sofijił Klarin. Zagreb : Hnatsko knjižniäarsko dnuștvo, 2001.

${ }^{17}$ Kutic, Tinku. Digitalizacija stare grade. // Vjesnik bjbliotskara Hrvatske 46, 3-4(2003), 41.

3 Verona, Eva. Pravilnik i priruenik, p. 192.

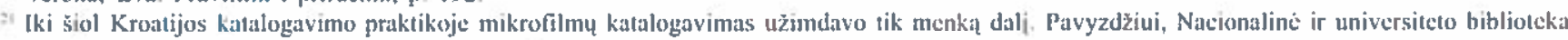
pradejo kataloguoti !aikrašciu mikrofílmus tik 2002 metais.

" Verona, Eva. Upute za medunarodni standardni bibliogralski opis bibliotečne grade : (Program Medunarodnc foderacije bibliolekarskilı drušłava i ustanova). // 2. jugoslavensko savjetovanje o primjeni kompjutora u bibliotckama, Zisgrcb, 28-30. ožujka 1977. Zagreb : Hrvatsko bibliotekarsko društvo, 1977. (lzdanja Hrvalskoga bibliotckarskog društva ; knj. 15). pp. 86-87.

${ }^{29}$ Problema, apic kurią E. Verona kalba savo straipsnyje, taip pat buvo nagrinèjama Dvišimiojoje bibliografinús apskaitos konferencijojes, skirtoje naujajam tūkstantmę̇itui ir vykusioje Kongreso bibliotckoje $2002 \mathrm{~m}$. Joje buvo nutarta, kad jvairioms formoms aprašyti reikia sudaryti atskirus ¡rašus ir patcikti jrašus kaip grups. nes tai atitiktı katalogo vartotoju poreikius. 


\section{Skaitmeninių reprodukcijų irašo formato pasirinkimas}

Tyrimu, kuri 1999 m. JAV bibliotekose atliko Jutta Reed-Scott, siekta išsiaiškinti, koks ịrašo formatas naudojamas skaitmeninimo projektuose $e^{24}$. Rezultatai parodé, kad aukštos kokybès MARC21 formatas nenaudojamas, paprastai dél laiko ir finansavimo stokos, todél labiau taikomi kiti ištekliaus aprašo būdai. Diđelèje dalyje projektų ištekliams aprašyti naudojamas Dublin Core formatas ${ }^{25}$, tuo tarpu kiti ịrašai sudaromi skaitmeninių fondц lygiu ${ }^{26}$ arba netiesiogiai per archyvines paieškos priemones ${ }^{27}$. Katalogavimo išlaidos toliau didejja, nes, remiantis ilgalaikio elektroninių ištcklių išsaugojimo standartu, sukuriami administraciniai ir struktūriniai ištekliaus ${ }^{28}$ duomenys. Naudojant tradicinius kompiuterinio katalogavimo formatus (MARC2 l, UNIMARC ir t. t.), bandoma vadovautis rekomendacijomis, vartojamomis aprašant naujus elektroninių ištekliu tipus, tarp jų ir skaitmenines reprodukcijas.

UNIMARC formatas leidžia taikyti ịvairius reprodukcijos aprašų modelius, kurie yra detaliai nusakyti UNIMARC taikymo aprašant mikroformas metodikoje ${ }^{29}$. Atsižvelgiant i i ivairias katalogavimo taisykjes, metodikoje siūlomos ivairios duomenł apic reprodukcija pateikimo galimybès. Reprodukciją galima aprašyti kaip atskirą ịaša kuris yra originalaus irašo kopija, pateikiant pastabą apie reprodukcija ir (arba) nuoroda i originala (1.1.0 ir 1.2 modeliai). Ją taip pat galima apibūdinti pastaboje, pridètoje pric originalo irašo (1.1.I modelis) arba kaip atskirą reprodukcijos įrašą su pastaba apie originalą ir (arba) nuoroda ị originalą ( 2.1 ir 2.2 modeliai) ${ }^{30}$.

Jei reprodukcijai yra sudaromas atskiras irašas, UNIMARC formato laukuose rašomos pastabos apie originalą ir reprodukciją (324 laukas (originalo versijos pastaba), 325 laukas (reprodukcijos pastaba), taip pat 4-- bloke susiejami originalo ir jo reprodukcijos irašai (455 laukas (reprodukcija is leidinio) ir 456 laukas (reprodukcija kaip)). Trečiajame antrosios UNIMARC Manual: Bibliographic Format laidos atnaujinime 135 lauke (koduotų duo- menų laukas: elektroniniai ištekliai), pateikiama daugiau kodų taikomı̨ skaitmeninių reprodukciju savybèms, tipui ir paskirčiai ivardyti. Koduoti duomenys taip pat gali patenkinti reikalavimus, keliamus ilgalaikiam vieneto išsaugojimui $^{31}$, be to, katalogo vartotojai gali sužinoti reprodukcijos tipa ir kokybę, nes taip pat pateikiama informacija apie elektroninio ištekliaus tipa, vieneto spalvą ir garsą, reprodukcijos spalvų skaičiu, suglaudinimo laipsnị, skaitmeninio performavimo kokybę ir t. t. Taigi, pavyzdžiui, daugiakalbio grupinio katalogo EROMM 135 koduotu duomenų laukas gali būti automatiškai išverstas i anglụ kalbą ir išspausdintas, tokiu būdu pateikiant kataloga užsiprenumeravusiems vartotojams informaciją apie dominančios reprodukcijos tipq.

Sudarant skaitmeninių reprodukcijų bibliografinius įrašus, galima naudotis Guidelines for Using UNIMARC for Electronic Resource Description (,UNIMARC taikymo aprašant elektroninius išteklius metodika") $)^{32}$.

\section{Skaitmeninių reprodukcijų versijų aprašymas}

Kiekvienas bibliografijos centras gali pasirinkti, ar aprašyti visas skaitmeninès reprodukcijos versijas viename bibliografiniame iraše, ar kiekvienai sudaryti po atskirą bibliografini irašą ${ }^{33}$. Jei kickvienai versijai sudaromi atskiri bibliografiniai irašai, padidéja katalogavimo darbų apimtis, todèl šios procedūros dažnai vengiama, apie versijas rašomos tik pastabos arba apie jas pažymima fondo duomenyse.

Šio tipo ištekliai išsiskiria tuo, kad atskiras reprodukcijos versijas galima laikyti fizinėse laikmenose (vienos ar daugiau rūšiu, t. y. ištekliai, apibūdinami kaip vietinès prieigos ištekliai ir viena ju versija, esanti internete ar vietiniame bibliotekos tinkle, jau laikomi nuotolinès prieigos išlekliais. Nèra iprasta skajtmeninès reprodukcijos iraše pateikti tik nuotolinès prieigos versijos apibūdinimus, tuo tarpu duomenys apie skaitmeninị originalą ir kitas vartotojo kopijas apibūdinami kaip kitos sistemos dalis, t. y. kaip suskaitmenintų išteklių duomenų bazès.

\footnotetext{
${ }^{24}$ Reed-Scott, Jutta. Cataloging of resources digitized for prescrvation. http://www.arl.org/spec/249fly html (2003-24-04),

${ }^{25}$ Daugiau informacijos apic Dublin Corc taikymą, aprašant suskaitmenintus išteklius, żr.: Cromwell-Kess/er, Willy. Dublin Cote metadata in the RLG information landscape, // D-lib magazine, December 1997. http://www,dlib org/dlib/december97/12cromwell-kesslcr.htm! (2003-02-28).

36 $\mathrm{Cf}$ : Dunsire, Gordon. Development of a relational database schema for colleclion-level descriptions in SCONE, the Scottish Collection Network. // 7. seminar Arhivi, knjižnice, muzeji : mogućnosti suradnjc u okruženju globalne informacijske infrastrukture : zbornik radova / edited by Tinka Katič. Zagreb : Hirvatsko knjižničarsko društvo, 2004. pp. 58-68.

${ }^{27}$ Reed-Scolt, Jutta, Jbid.

28 Śo straipsnio tikslas nèra diskutuoti apte šio tipo suskaitmenintu ištekliu aprašą. CC.: Willer, Mima. Metapodaci za dugoročnu zaštitu elektroničke građe. // 5. seminar Arhivi, knjižñce, muzeji : moguçnosti suradnje u okružcenju globalne informacijske infrastrukture : zbornik radova / uredile Mirna Willer i Tinka Katić. Zagreb : Hrvatsko knjižnjżarsko društvo, 2002. pp. 55-69.

s Guidclines for using UNIMARC for microforms. www.ifla.org/VI/3/pl996-1/guid2.htm (1999-05-01).

to Ibid, p. 7.

"Cf: Willer, Mima. Ibid.

${ }^{12}$ Smjernice za uporabu formata UNIMARC za opis elektroničke grade / prevela i hrvatske primjerc izradila Sofija Klarin. http://www.nsk.hr/ c-izdanja/421118093.htm (2003-11-01).

${ }^{31}$ ISBD(ER), p. 13.
} 


\subsection{ISBD(ER) taikymas}

Bibliografijos centras, nusprendęs keletą skaitmeninés reprodukcijos versijų aprašyti viename bibliografiniame iraše, gali vadovautis ISBD(ER) ižanginèse pastabose pateiktomis rekomendacijomis apie ivairiomis formomis, laikmenomis ar formatais pricinamu ištekliu fizini apraša. Duomenys apie versijas gali būti pateikiami fizinio aprašo toje pačioje eiluteje arba is naujos eilutés. Toliau is̆ ISBD(ER) pateikiami pavyzdžiai, iliustruojantys duomenis apic skirtingas fizines laikmenas.

\section{Pavyzdns \\ . - 1 optinis diskas, 3 diskeliai, I vadovas}

Pavy=dis

. - I optinis diskas (CD-ROM) : gars,, spalv.; $12 \mathrm{~cm}$

. -3 diskeliai: gars., spalv, ; $9 \mathrm{~cm}$

. -1 vadovas $(123$ p.) $; 20 \mathrm{~cm}$

ISBD(ER) nenurodoma, kokią procedūrą reikètų taikyti, jei versijos yra tose pačiose laikmenose, bet skirtingu atvaizdavimo formatu, t. y. nepatcikiamas pavyzdys, kaip aprašyti skirtingas versijas, laikomas tos pačios rūšies fizinèse laikmenose arba prieinamas žiniatinklyje. Pavyzđtžiui, dvi skaitmeninès reprodukcijos versijos (originalas ir vartotojo kopija) gali būti laikoma vienos rūšies laikmenoje (pvz., CD-ROM arba DVD), o viena versija pricinama internete, Kaip aprašyti daugiau versijų, laikomụ tos pačios rūšies laikmenose, galima pasirinkti, vadovaujant is taikomais standartais ${ }^{34}$. Jei anksčiau pateiktas modelis būtu taikomas aprašyti versijoms tik viename reprodukcijos bibliografiniame iraše, versijų fizinius duomenis būtı galima pateikti toje pačioje eilutèje arba kiekvienos versijos naujoje eilutèje ${ }^{35}$. Kadangi ISBD(ER) nenurodoma, jog galima turinio rūšis išvardyti kaip fizinio aprašo dali, vartotojas negali susidaryti aiškaus vaizdo apie skirtingas versijas, todèl būtu geriau vadovautis ISBD(NBM) ir jo skyriumi apie mikrografiniı reprodukcijų fizjni aprasą kaip taisyklemis tuo atvcju, kai aprašoma keletas skaitmeninjų reprodukcijų versiju.

\subsection{ISBD(NBM)}

Kaip jau mincta, mikrografinés reprodukcijos yra panašios i skaitmenines reprodukcijas: norint naudotis abicju rūšiu ištekliais, būtina speciali ịranga; paprastai abiejụ rūšị ištekliams skirtingiems tikslams pagaminama keletas originalios reprodukcijos versiju; pastebima ir keletas panašumų tarp šiu reprodukcijų clarakteristikų ir paskirties. Skirtumaj iš esmés atsiranda dẻl šių laikmenı̨ funkcionalumo, kuris ypač akivaizdžiai matyti tuomet, kai reprodukcijos turi büti prieinamos internete kuo didesniam vartolojui skaičiui, tuo tarpu mikrofilmo privalumas pirmiausia yra jo jlgalaikiškumas.

Skirtumai pastebimi ir tarp kai kuriı ju aprašo elementų. Pavyzdžiui, elektroninių išteklių apraše taipp pat nurodomi sistemos reikalavimai, tuo tarpu mikrofilmo apraše nepateikiami jokie duomenys apie reikalingus prietaisus. Kalbant apie versijas, svarbiau pažymèti, kad pagal ISBD(NBM) nurodymus, mikroformos aprašo fiziniuose duomenyse galima patcikti jos rūši, taip pat mikrofilmo reprodukcijos versija 5 srityje (5.2,2 skyrius).

Pavyzdes

. - I mikrofilmo rite : diazo

P a $s \mathrm{t}$ a b a. Diazo (šviesai jautrus) filmas vartojamas tarpinéms originalo kopijoms sukurti.

Be to, ISBD(NBM) rekomenduojama pateikti ir vaizdo sumažinimo santyki, kai sumažinimo santykis skiriasi nuo standartinjo santykio (5.2.3.1 skyrius) arba kai neimanoma sumažinimo santykio tiksliai apibrèžti (5.2.3.2 skyrius).

\section{Pavyzdaiai \\ - - I mikrofilmo ritè : diazo, $14 x$ \\ - 3 permatomos mikrofišos : ypač didelis sumažinimas}

Abieju standartų nurodymų suderinimas padètı̨ bibliografijos centrams apibréžti versijų aprašus, nes šituo metu jic apibūdina versijas (tick mikrografiniŁ̧, tiek skaitmeninị reprodukciju) viename bibliograf̆niame įraše. Pritaikius ISBD(ER) 5 srities nurodymus mikrografīniu reprodukciju aprašui, būtu galima viename įraše išvardyti daugiau mikroformų rūšiu ar versiju, tuo tarpu taikant 5 srities nurodymus, palciktus ISBD(NBM), būtų įmanoma išvardyti versijos detales, kurias reikia ịtraukti i skaitmeninès reprodukcijos fizini aprašą. Taip bütu galima lengviau peržiūrèti keleto reprodukcijos versiju fizinius duomenis, nes jos būty apibūdintos viename bibliografiniame iraše.

\subsection{UNIMARC bibliografinis formatas}

Išvardyti skirtingu versijų duomen is viename bibliografiniame įraše galima kartojant 215 lauką (fiziniai duomenys), taip pat viename ịraše apibūdinti kelias versijas galima kartojant 135 lauką (koduotų duomeny laukas: elektroniniai tšı ekliai), kuriame galima pateikti kiekvienai versijai tinkančius koduotus duomenis.

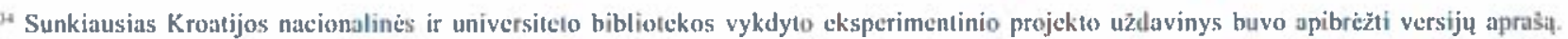

${ }^{15}$ 1šsamiau ว̆r. ISBD(ER), p. 82-83.
} 


\section{Skaitmeninių reprodukciju katalogavimas} vykdant Kroatijos nacionalinès ir universiteto bibliotekos eksperimentinị ištekliu skaitmeninimo projektą

Kai $2001 \mathrm{~m}$. Nacionalinès ir universiteto bibliotekos darbuotojai pradèjo vykdyti eksperimentini ištekliu skaitmeninimo projektą, vienas pagrindinių jo tikslų buvo nustatyti skaitmeninių reprodukcijų, t. y. skaitmeniniu originalų ir vartotojo kopiju, aprašo modeli. Kuriant modeli remtasi pasiülymu įtraukti skaitmeniniц̨ reprodukciju aprašus i bibliotekos kataloga ir sudaryti bibliografinius irašus, kurie atitiktu ISBD reikalavimus ir nacionalines katalogavimo taisykles (kaip yra daroma su kitomis bibliotekos medžiagos rūšimis). Sudarant kompiuterinius irašus taip pat buvo sutarta taikyti UNIMARC.

Skaitmeninès reprodukcijos pirmiausia yra aprašomos kaip elektroniniai ištekliai, remiantis ISBD(ER) nurodymais, o specifiniai aprašo elementai, atsižvelgiant $i$ konkretụ reprodukuoto ištekliaus turinio tipa, pritaikomi iš kitụ ISBD, tinkančių konktečiai ištekliaus rūšiai (pvz., ISBD(CM) žemélapiams ir ISBD(PM) natu leidiniams) ${ }^{36}$.

Buvo nuspręsta, kad aprašant skaitmenines reprodukcijas bus sudaromas atskiras irašas, kuriame būtụ vartojami 4-- bloko laukai, pateikiantys originalo įrašą (žr. pav.), ir kad viename ịraše bus apibūdinamos visos skaitmeninés reprodukcijos versijos. Tokiame ịaše tiek vartotojai, tiek bibliotekininkai galès aiškiau matyti ivairias konkretaus kūrinio formas, be to, bus išvardytos visos prieinamos versijos. Šiuo tikslu buvo peržiūrèta bibliotekos informacijos sistema CROLIST, leidžianti sudaryti reprodukcijų irašus, kopijuojant originalo ịrašą ir papildomai itraukiant lauką, kuriame aprašoma reprodukcija. Galimybẻ kopijuoti ịašus sutaupo nemažai kataloguotojų laiko, nes nukopijuotą reprodukcijos irašą tereikia šiek tiek papildyti atitinkamais duomenimis.

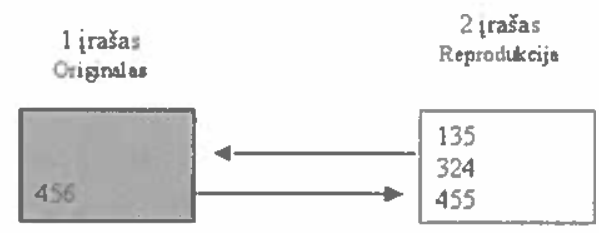

Taip pat buvo nuspręsta keleto skaitmeninès reprodukcijos versiju fizinio aprašo elementus itraukti pagal ISBD(ER) ir ISBD(NBM) atitinkamus nurodymus. Kiekvienos versijos fiziniai duomenys rašomi iš naujos eilutès (vartojant pasikartojanti UNIMARC 215 lauka).

Pavyzdys

215\#\#a3 optiniai diskai (CD-ROM)

Scarchyvinès kokybès originalas

$\$ \mathrm{~d} 12 \mathrm{~cm}$

215\#\#Sal optinis diskas (CD-ROM)

\$cvartotojo kopija

$\$ \mathrm{~d} 12 \mathrm{~cm}$

215\#\#SaŽiniatinklio versija

P a s t a b a. Trys skaitmeninés reprodukeijos versijos apibūdintos viename iraše.

Pagal anksčiau aptartus sprendimus i irašą taip pat reikia itraukti ir pasikartojanti 135 lauka (kođuotu duomenų laukas: elektroniniat ištekliai) kiekvienai skaitmeninès reprodukcijos versijai.

Taikant ISBD(NBM) nurodymus, fizinị aprašą galima dar labiau išplèsti itraukiant kitas fizines detales, pavyzdžiui, duomenis apie sumažinimo santyki, kai aprašomos tarpinès kopijos ir vartotojo versijos, arba failo formała, kuris taip pat atskleidžia suglaudinimo lygi. Jei reikia, pastaboje taip pat galima pateikti duomenis apic failo dy$\mathrm{di}^{37}$.

Buvo itraukti ne tik elektroninių išteklių aprašo elementai (pvz., pastaba apie sistemos reikalavimus, pastaba apie kreipties būdq, bendras medžiagos apibūdinimas, kuris Kroatijos nacionalinès ir universiteto bibliotekos praktikoje visada pateikiamas elektroniniu ištekliụ irašuose, ir t. t.), bet ir apibréžti specifiniai skaitmeninių išteklių apraso elementai.

Originalo publikavimo duomenys ir suskaitmenintos jo kopijos šifras, irašytas pastaboje apie kūrinio bibliografinę istoriją, taip pat itraukiamas i reprodukcijos iraša. Jei nors viena fonde saugoma originali kopija suskaitmeninama, i ịrašą reikia ịtraukti ne tik šifrą, bet ir duomenis apie skaitmeninimui naudotą kopiją ${ }^{38}$.

\footnotetext{
36 Pagal ISBD(ER), bibliografijos centras gali pasirinkti [vairiu formy leidinị aprašo büdq. Rekomenduojama pirmiausił taikyti ISBD(ER), o tik paskui, jei reikia, kitus ISBD. Kai kurios rekomendacijos buvo parenglos pagal IFLA Katalogavimo sckeijos ISBD peržiüros grupés nurodymus. Cf. Treatment of publications in multiple formats : initiated by the IFLA Section on Cataloguing ISBD Review Group http://wwwifla.org/VII s13/pubs/multiplefrm.htm (2002-1 l-03). Tačiau peržiūrélame ISBD(ER) projekte rekomenduojami kiti, daugian tinkantys ISBD ir po to taip pat ISBD(ER). Galbüt toks siülymas rodo, kad ISBD(ER) gali büti traktuojamas tarsi ISBD(G) elektroninjams ištckliams, kuriame patcikiami

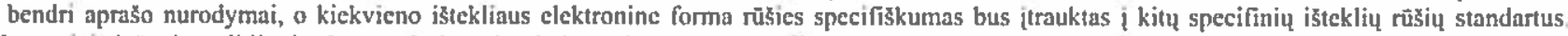

${ }^{37}$ Vartotojai dažnai pasikliauja duomenimis apie skaitmeninès reprodukcijos ypatybes. Pavyzdžiui, leidẻjai nori sužinoti, ar galima pagerinti konkrečios nuotraukos kokybę, kad ši atitiktu tam tikrus spausdinimo standartus, arba asmeniui, ieškančiam interneto failu, gałi parūpti, kiek laiko užims perkelti reikalingus duomenis żiniatinkliu.

"a Nuspręsta, kad i pastabą ncbus jitraukiami išsamūs originalo leidybintat duomenys, katp buvo nurodyta Vadovo 236/8 straipsnyje, apraక̌ant senuosius leidinius, kadangi peržvelgti originalo irasła galima spustelćjus sąsajł 455 lauke.
} 
Pavyzdžiai

324\# SaSkailmeninè $1650 \mathrm{~m}$. laidos reprodukcija; S-JZ-XVII-23 324\#\$Skaitmeninè $1522 \mathrm{~m}$. laidos reprodukcija; RIIC-80-100 b kopija

Ištekliaus vartojimo sqlygos rašomos 333 lauke (pastaba apie numatomus vartotojus) ${ }^{34}$. Šios pastabos turinys yra suderintas su bibliotekos pasirinktu prieigos būdu ir eksperimentinio projekto skaitmeninių reprodukcijų vartojimo sąlygomis, o vẻliau ji reikès pakoreguoti pagal projekto tipą ir medžiaga, pasirinktą skaitmeninimui, bei prieigos sąlygas.

Pavyadys

333H\#\$aTik asmeniniais arba moksliniais tikslais; dauginti draudžiama; skaitmeninés ir spausdintinès reprodukcijos gaminamos tik pateikus prašymą

336 laukas (elektroninio ištekliaus tipo pastaba) gali būti vartojamas versijų failo/failu tipui ir apimčiai apibūdinti, jei šie duomenys nẻra ịtraukti i fizini aprašą arba tais atvejais, kai tai yra vienintele reprodukcijos versija.

Pavyzdys

336\#\#\$Failo tipas: skaitmeninis originalas 336\#\#\$aFailo tipas: archyvinés kokybès originalas (90 MB)

I tą patị lauka taip pat galima ịtraukti duomenis apie skaitmeninių reprodukciju raišką ir formatus ${ }^{40}$.

Pavyzdys

336\#\#\$aOriginalas, suskaitmenintas 300 tašk»/colyje TIFF formatu; vartolojo kopijos JPEG formatu

Projekto metu buvo parengtas dokumentas, apibrèžiantis skaitmeninių reprođukcijų aprašo modeli ir elementus pagal anksčiau minćlus standartus ir nutarimustl.

Pasirinklas skaitmeninių reprodukcijų aprašo modelis buvo išbandytas eksperimentinio projekto metu, o galutinai modelis bus ivertintas po to, kai bus pritaikytas didesniam ịrašų skaičiuit2.

\section{Neišspręsti klausimai: suskaitmenintıł originalo priklausomų dalių aprašas}

Suskaitmenintụ reprodukcijų aprašo modelis buvo analizuojamas, remiantis originalo visumos reprodukcijomis. Tačiau bibliotekos dažnai pasirenka skaitmeninti tik dalị kūrinio, norèdamos pristatyti tik atrinktus ju fondo kūrinius arba sumažinti skaitmeninimo išlaidas, todèl sukuria vadinamas stskaitmenintas originalo priklausomas dalis. Tokias suskaitmenintas priklausomas dalis gali sudaryti tik viršeliss, turinys, santraukos, iliustracijos, Ientelès ir t. t., o senuju leidiniu gali būti suskaitmenintos atrink tos turinio dalys, pavyzdžjui, iliuminacijos, marginalijos arba išorinès vieneto ypatybės, pavyzdžiui, įrišimas, sąsagos ir t. t.

Aprašant suskaitmenintas originalo priklausomas dalis visu pirma iškyla problema dèl to, kad aprašomos dalys yra nepriklausomos savo turiniu, tačiau priklausomos bibliografinių apibūdinimų atžvilgiu, kitaip tariant, problema aprašant kūrinio atspaudus, ištraukas ar paragrafus. Smulkinimas arba skaidymas, kaip bendras elektroninił̨ ištekliu bruožas, skatina persvarstyti, kokio detalumo turétụ būti suskaitmenintos medžiagos aprašai. Bibliotekoms iškyla klausimas „kaip apibrèžti bibliografini vienetą skaitmeniniame kontekste? ${ }^{\text {*4] }}$ ir ar būtina sudaryti papildomus atskirus įrašus suskaitmenintoms originalo priklausomoms dalims, t. y. tokiems vienetams, kurie tradiciškai buvo kataloguojami kaip vieno bibliografinjo vieneto dalys ${ }^{44}$. Kas sudaro savarankišką bibliografini vieneta, turint omenyje, kad bet kuri kūrinio ištrauka gali būti suskaitmeninta, laikoma arba pateikiama kartu su kitomis panašiomis ištraukomis arba gali būti vartojama kaip savarankiškas entitetas? Kokiais kriterijais reikètu vadovautis, sprendžiant, kuris entiletas sudaro vieną bibliografini vienetą?

Aleksandra Horvat plètoja mintị apie bibliografinių vienelų apibrčžimo ir katalogo vienetų sudarymo procedūras, pabréždama, kad kūrini galima apibūdinti kaip nepriklausoma vieneta, remiantis tam tikrais katalogo reikalavimais arba tam tikra konkrečios bibliotekos bibliografine politika ${ }^{45}$. Ar reikètu suskaitmenintas išrtraukas apibūdinti kaip „tam tikros reprodukcijos" tipa? Kokia ju reikšmé atskirai nuo leidinio, kuriam jos priklauso, konteksto ir

\footnotetext{
333 laukas pasirinktas ką̣ labiausiaj tinkantis j̨traukti duomenis apic suskaitmeninto ib̆lekliaus vartojimo sq̨ygas.

a Pagrinda, kuriuo galima remtis pateikiant techninius reprodukcijos duomenis, galima rasti Jadove: $236 / 8$ straipsnyje rekomenduojama, kad "faksimiles kopjju katalogo aprašus (...) Ituri sudaryti pastabose patcikiami kiti svarbūs duomenys apic originalą, duomenys apic kopijavimo teclunika ir duomenys apic originalo publikavima ir (arba) spausdinimą".

${ }^{2}$ Klarin, Sofija. Upute za kalalogiziranjc digitalnjh reprodukcija. Zagreb : Nacionalna i sveucilišna knjižnica, 2005. (projekto versija).

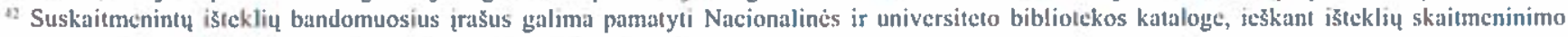
eksperimentinio projekto antraštès. URL: http://www.nsk.hr

4) Cf: Jonsson, Gunila. The bibliograplic unit in digital context - how 10 defint it?: Working Group 4 report / Ist International Meeting of Experts on an International Cataloguing Code, Frankfurt, Germany, July 28-30, 2003. httpi//www.ddb.de/standardisierung/puf/papers jonsson.pulf

4 Recd-Scott, Jutta. Ibid., p. 3.

t5 Horval, Alcksandra. Abecedni katalog̣ i autorstvo. Rjjuka : Benja, 1995. pp. 34-35.
} 
kokios rūšies informaciją jos pateikia vartotojui? Kokiu būdu reikètu jas susieti su leidinio, kuriam jos priklauso, bet kita laikmena, irašu? Šiuos klausimus galima praplèstł taip, kad jie apimtų ir bibliotekos katalogo funkciją.

Vienas iš realistiškesnių būdų rasti sprendimą būtų: atskirti vienetus, apibūdinamus kaip nepriklausomi kūriniai (pavyzdžiui, žemélapiai iš atlaso, straipsniai iš žurnalo ir t. t.), nuo mažesnès apimties vienetų dalių (pavyzdžiui, santraukos, vieneto turinio puslapiai, pirmasis pustapis arba puslapiai, kuriuose pateikiamas sąrašas ypatybiu, susijusiı̨ su konkrečiu vienetu, pavyzdžiui, ankstesnių savininku parašai, trišimas, apgadinti puslapiai ir t. t.), kurias reikẻtų apibūdinti kaip priklausomas kūrinio dalis.

Nepriklausomų kūrinių skaitmenines reprodukcijas būtu galima aprašyti kaip atskirus vienetus, t. y. sudedamuosius arba analizinius vienetus. Tokius irašus reikètu susieti su originalo, t. y. leidinio, kuriam jie priklauso, irašu.

Visai priimtina suskaitmenintas kūrinio priklausomas dalis apibūdinti tik pastabose (pvz., pastaba apie aprašomą kopija, remiantis penktuoju antrosios „UNIMARC vadovo" laidos atnaujinimu" ${ }^{\text {th }}$. Kai kurie laukai papildyti polaukiu Su, skirtu pateikti URL, prie pastabos pridètomis sąsajomis, nurodančiomis vartotojui skaitmeninę reprodukciją, iliustruojančią ir paaiškinančią pastabos turinįi7.

Pavy $=d y, s$

$316 \#$ HSaBaltos odos irišimas \$5NSB, RIIC-80-100 b kopija

\$uhttp://nskcrolist.nsk.hr/judita/uvez.htm]

$317 \# \#$ \$aAnotacija glagolica pirmojo puslapio viršuje \$uhttp://nskcrolist.nsk,hr/knjiga l/nasl-str.html

320\#\# SuTin Ujević bibliografija: p. 176-178

Suhttp://nskcrolist.nsk.hr/ujevic/bibliografija.html

P a s t a b a. Pavyzdžiuose pateikti adresai yra išgalvoti.

Kyla papildomas klausimas, susijęs su to paties autoriaus arba skirtingų autorių nepriklausomų kūriniı aprašu arba anoniminių kūrinių neturinčį̣ bendrosios antraštés ir dèl paprastesnio vartojimo laikomų vienoje fizinèje laikmenoje, aprašu (pvz., 100 žemẻlapiŁ reprodukcijos viename DVD). Nesiveliant i gilesnes diskusijas apie tai, ar vienetą reikétų traktuoti kaip rinkinio apraša, ar ne, verta pastebéti, kad pagrindinés aprašo problemos kyla dẻl to, kad skaitmeninių reprodukcijų fizinè laikmena nèra (leidè- jo) nustatyta konstanta, bet yra iprasta ir reikalinga procedūra, leidžianti perkelti medžiaga î kitą laikmeną tam, kad būtu apsaugotas medžiagos turinys, pavyzdžiui, iš CD-ROM failai perkeliami i DVD arba skaitmenini archyvą. Skaitmeninių reprodukcijų aprašas taip pat patvirtina, kad stiprūs tarpusavio ryšiai sieja elektroninių išteklių katalogavimo procesą ir ju išsaugojimo priemones.

\section{Išvados}

Vadove rekomenduojami skirtingose laikmenose laikomų reprodukcijų katalogo aprašo modelis ir elementai gali padèti apibréžti skaitmeninių reprodukcijų aprašo modelị ir elementus. Skaitmeninés reprodukcijos aprašomos, remiantis ISBD(ER) ir kitais ISBD, atitinkančiais specifines ištekliu rūšis. ISBD(NBM) nurodymus, taikomus aprašant mikroformas, taip pat galima pritaikyti sudarant aprašo elementus, susijusius su tam tikru reprodukcijos pobūdžiu.

Kalbẻdama apie didesnio skaičiaus ISBD vartojimą aprašant išteklius, Eva Verona pabréžè: „Poreikis tuo pačiu metu taikyti du ar daugiau ISBD, sudarant vieną apraša, aiškiai rodo, kad šių rekomendacijų nėra ir jụ nereikètu traktuoti kaip visiškai savarankiškų dokumentı, o kaip dokumentus, kurie yra glaudżiai susiję tarpusavyje ir tik kartu gali suformuott vieną visumą. Glaudūs ryšiai patvirtina, jog būtina rekomendacijas abipusiškai suderinti's48.

Norint užtikrinti ilgalaiki išteklių išsaugojima, labai svarbu sudaryti atskirus bibliografinius irašus originalui ir jo skaitmeninei reprodukcijai, nes tada galima organizuočiau itraukti duomenis apie reprodukcijos fizines ir technines detales, vartojimo teisių ir sąlygu duomenis bei koduotus duomenis, reikalingus ilgalaikiam išsaugojimui.

Atsižvelgiant i katalogo irašų tvarkymą duomenų bazejje, sudarius atskirus ịrašus galima kokybiškiau ieškoti irašu, kuriuose pateikjami atitinkami koduoti duomenys, taip pat vartoti irašus kooperuoto katalogavimo sistemose. Be to, atskirais skaitmeniniu reprodukciju bibliografiniais įrašais galima keistis arba juos perkelti (tuo pačiu arba skirtingu formatu) i kitą duomenų bazę (pvz., bazę, kurioje kaupiami tik elektroninių išteklių irašai). Atskiri irašai taip pat leidžia surinkti duomenis per protokolus, skirtus metaduomenu rinkimui, pavyzdžiui, OAI-PMH (Open Archives Initiative Protocol for Metadata Harvesting's).

\footnotetext{
4h UN[MARC manual : bibtiographic format / International Federation of Library Associations and [nstitutions, IFLA Universal Bibliographic Control and International MARC Programme. 2nd ed. Update 5. München : K.G. Saur, 2005. (UBCIM Publications. New Scrics, vol.14).

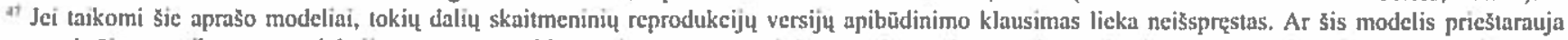
anksčiau patciktam reprodukcijos aprašymo atkiruose łrašsuose modeliui (kartu išvardijant ir visus reikalingus duomenis apic reprodukcija). $t$. y. kuri bibliotekos sistemos dalis bütụ atsakinga už suskattmenintų kürinio priklausančiu daliu aprašus?

4 Veronn, Ëva. Upute za međunarodni standardni bibliografski opis bibliotečne grade : (Progran Medunatodne federacije bibliotekarskih društava i ustanova), p, 87

${ }^{14}$ Išsamiau żr: Melinš̨̌ak Zlodi, Iva; Martina Melinščak. OA!@AKM.
} 
Paprasčiau pateikti duomenis vartotojams ir lengviau rasti ¡vairias kūrinio formas būtų galima sukūrus grupinị ịrašu pateikima kaip siūloma FRBR modelyje $e^{50}$.

Pagal ISBD(ER) nurodymus, skaitmeninés reprodukcijos irašą gali sudaryti keleto reprodukcijos versiju aprašas, nors taip pat galima sudaryti ir po atskirą irašą kickvienai reprodukcijai. Sprendimą dél skaitmeninių reprodukcijų versiju aprašo, taip pat i nacionalines katalogavimo taisykles neitrauktı̨ kitų aprašo elementų, reikẻtų priimti kartu su katalogavimo istaigomis, suinteresuotomis skaitmeninėmis reprodukcijomis, atitinkamais ekspertų komitetais ir katalogavimo ekspertais.

Kadangi skattmeninimo projektai toliau tobulinami, ribos tarp tam tikrų skaitmeninių reprodukcijų aprašu tipu ir vartotojams bei bibliotekininkams svarbiu aprašo elementų taps aiškesnès, t. y. ryšia tarp aprašomuju ir kitokio tipo duomenu bibliotekų kataloguose, skaitmeniniuose archyvuose ar kitose sistemose, skirtose skaitmeniniu išteklių tvarkymui, taps labiau apibrèžti.

Iš anglı kalbos vertè S. Raceviciūtè

\footnotetext{
\$o Functional requisements for bibliographic records : final report / IFL $\Lambda$ Study Group on the Functional Requirements for Bibliograplyic Records ;
} approved by the Standing Committee of the JFLA Section on Cataloguing. München : Saur, 1998. 


\section{LITERATŨRA}

Benchmark for faithful digital reproductions of monographs and serials : version 1. / The Digital Library Federation Benchmark Working Group (2001-2002). http://www.diglib.org/ standards/bmarkfin.htm (2003-05-13).

Cole, Jim E. The cataloging of digitized texts. // Cataloging \& classification quarterly $28,3(1999), 45-54$.

Copeland, Ann. Works and digital resources in the catalog : electronic versions of Book of Urizen. The Kelmscott Chaucer and Robinson Crusoe. // Cataloging and classification quarterly $33,3-4(2002), 161-180$.

Cromwell-Kessler, Willy. Dublin Core metadata in the RLG information landscape. // D-lib magazine, December 1997. http://www.dlib.org/dlib/december97/12cromwell-kessler.htm] (2003-02-28).

Draft interim guidelines for cataloging electronic resources. http://lcweb.loc.gov/catdir/cpso/demb19 4.html (2004-02-04).

Dunsire, Gordon. Development of a relational database schema for collection-level descriptions in SCONE, the Scottish Collection Network. // 7. seminar Arhivi, knjižnice, muzeji : mogućnosti suradnje u okruženju globalne informacijske infrastrukture : zbornik radova / edited by Tinka Katič. Zagreb : Hrvatsko knjižničarsko društvo, 2004. Pp. 58-68.

Functional requirements for bibliographic records : final report I IFLA Study Group on the Functional Requirements for Bibliographic Records ; approved by the Standing Committec of the IFLA Section on Cataloguing. München : K. G. Saur, 1998.

Guidelines for using UNIMARC for microforms.

http://ww.ifla.org/VI/3/p1996-l/guid2.htm (2003-03-22).

Horvat, Aleksandra, Abecedni katalog j autorstvo. Rijeka : Benja, 1995.

IFLA-ina načela za skrb i rukovanje knjižničnom gradom / sastavio i uredio Edward P. Adcock u suradnji s MaricThérèsom Varlamoff i Virginiom Kremp ; [prevela s engleskoga Koraljka Golub ; uredila i usuglasila s engleskim izvornikom i stručnim nazivljem na području zaštite Tatjana Mušnjak]. Zagreb : Hrvatsko knjižničarsko društvo, 2003.

Images for web delivery. http://www.nla.govau/digital/ delivery.html (2003-10-10).
IME ICC : report of the Ist Meeting, Frankfurt, Germany, July 28-30, 2003 / reported by Barbara B. Tillett. http://www.ddb. de/news/pdf/ime_icc_report_berlin.pdf (2003-10-02).

ISBD(ER) : International standard bibliographic description for electronic resources : draft for world wide review / recommended by the ISBD Review Group ; proposed for approval by the Standing Committee of the IFLA Cataloguing Section. 2004. revision. http:/www.ifla.org/VII/s 13/gujde/isbder_ww2]-04.pdf (2004-02-06).

ISBD(ER) : Međunarodni standardni bibliografski opis elektroničke grade : prerađeno izdanje ISBD(CF)-a : Međunarodnoga standardnoga bibliografskog opisa racunalnih datoteka / preporučila Radna grupa za pregled ISBD(CF)-a ; s engleskog prevele, hrvatske primjere odabrale $\mathrm{i}$ izradile Tanja Buzina j Sofija Klarin. Zagreb : Hrvatsko knjižničarsko društvo, 2001.

ISBD(G) : General international standard bibliographic description : annotated text / prepared by the ISBD Review Committee Working Group set up by the IFLA Committee on Cataloguing. Rev. ed. München [etc.] : Saur, 1992.

ISBD $(G)$ : General international standard bibliographic description : draft for world wide review / recommended by the ISBD Review Group. 2003 revision.

ISBD(NBM) : Medunarodni standardni opis neknjižne grade / preporučila Komisija za pregled ISBDa ; s engleskoga prevela, hrvatske primjere odabrala i izradila Vedrana Juričić. Prerađeno izd. Zagreb : Hrvatsko bibliotekarsko društvo, 1993.

Jonsson, Gunilla. The bibliographic unit in digital context how to define it?: Working Group 4 report / 1st Intemational Meeting of Experts on an International Cataloguing Code, Frankfurt, Germany, July 28-30, 2003. http://www,ddb,de/ standardisicrung/pdf/papers_jonsson.pdf (2006-05-06).

Katić, Tinka. Digitalizacija stare grade. // Vjesnik bibliotekara Hrvatske 46, 3-4(2003), 33-47.

Klarin, Sofija. Upute za katalogiziranje digitalnih reprodukcija. Zagreb : Nacionalna i sveuçilišna knjižnica, 2003. (radna inačica).

Princenik za UNIMARC : bibliografski format / prevela j priredila Mirna Willer. 2. hrvatsko izd. Zagreb : Nacionalna i sveučilišna knjižnica ; Hrvatsko knjižničarsko društvo, 1999.

Reed-Scott, Jutta. Cataloging of resources digitized for preservation. http://www.arl.org/spec/249fiy.html (2003-04-24). 
Report of the cataloging digital reproductions task force : revised draft. December 11, 1995 / Preservation Department at Yale University Library. http://www.library, yale.edu/ $\sim$ mbeacom/erepros2.pdf (2003-11-01).

Schwartz, Werner. On the imporiance of recording microforms and digitised versions produced for preservation on the international level, with a focus on standards. http:/liber.library. uu.nl/publish/articles/000055/article_content.htm (2003-12-I4).

Smjernice za uporabu formata UNIMARC za opis elcktroničke grade / prevela j hrvatske primjere izradila Solija Klarin. hitp:// www.nsk,hr/c-izdanja/421118093.htm (2003-10-02).

Standards for surrogates that are to be recorded in the EROMM database. http://www.eromm.org/standards.htm (2003-12-14).

Treatment of publications in multjple formats : initiated by the IFLA Section on Cataloguing ISBD Review Group. http:// www.ifla.org/VII/s] 3/pubs/multiplefrm.htm (2002-11-03).

UNIMARC manual : bibliographic format / IFLA Universal Bibliographic Control and International MARC Core Programme (UBCIM), 2nd ed., 3rd upd. München : K.G. Saur, 2002.

Verona, Eva. Pravilnik i priručnik za izradbu abecednih kataloga : drugi dio : kataložni opis. Zagreb : Hrvatsko bibliotekarsko društvo, 1983.
Verona, Eva. Upute za medunarodni standardni bibliografski opis bibliotečne grade : (Program Medunarodne federacije bibliotekarskih društava i ustanova) // 2. jugoslavensko savjetovanje o primjeni kompjutora u bibliotekama, Zagreb, 28-30. ožujka 1977. Zagreb : Hrvatsko bibliotekarsko društvo, 1977. (Izdanja Hrvatskoga bibliolekarskog društva ; knj. 15). Pp. 85-90.

Vrana, Radovan. Digitalni Babilon : utvrdivanje kriterija za vrednovanje kvalitete izgradnje i sadržaja digitalnih zbirkj i usluga. // 6. seminar Arhivi, knjižnice, muzcji : mogućnosti suradnje u okruženju globalne informacijske infrastrukture : zbornik radova/ uredila Tinka Katić. Zagreb : Hrvatsko Knjižničarsko društvo, 2003. Pp. 49-61.

Willer, Mima. Metapodaci za dugoročnu zaštitu elektroničke grade. // 5. scminar Arhivi, knjižnice, muzcji : mogućnosti suradnje u okruženju globalne informacijske infrastrukture : zbornik radova / uredile Mirna Willer i Tinka Katic. Zagreb : Hrvatsko knj̣ižničarsko društvo, 2002. Pp. 55-69.

Woollard, Mathew. Digital resources : challenging use or users" challenges : conference proceedings. // Examining the impact of digitization upon scholarship in the humanities, 7 July 2003. / Institute of Historical Research. http:// www.history.ac.uk/conferences/digitisation2003/woollard,/ntml (2003-12-12).

Zlodi, Goran. Muzejska vizualna dokumentacija u digitalnom obliku : magistarski rad. Zagreb : Filozofski fakultet, 2003. 